\title{
Sensitivity of Rhizoctonia solani AG-2-2 from Sugar Beet to Fungicides
}

\author{
Sahar Arabiat and Mohamed F. R. Khan, Department of Plant Pathology, North Dakota State University, Fargo 58108
}

\begin{abstract}
Arabiat, S., and Khan, M. F. R. 2016. Sensitivity of Rhizoctonia solani AG-2-2 from sugar beet to fungicides. Plant Dis. 100:2427-2433.

Rhizoctonia damping-off and crown and root rot caused by Rhizoctonia solani are major diseases of sugar beet (Beta vulgaris L.) worldwide, and growers in the United States rely on fungicides for disease management. Sensitivity of $R$. solani to fungicides was evaluated in vitro using a mycelial radial growth assay and by evaluating disease severity on $R$. solani AG 2-2 inoculated plants treated with fungicides in the greenhouse. The mean concentration that caused $50 \%$ mycelial growth inhibition $\left(\mathrm{EC}_{50}\right)$ values for baseline isolates (collected before the fungicides were registered for sugar beet) were 49.7, 97.1, 0.3, 0.2, and $0.9 \mu \mathrm{g} \mathrm{ml}^{-1}$ and for nonbaseline isolates (collected after registration and use of fungicides) were 296.1, 341.7, 0.9,

0.2 , and $0.6 \mu \mathrm{g} \mathrm{ml}^{-1}$ for azoxystrobin, trifloxystrobin, pyraclostrobin, penthiopyrad, and prothioconazole, respectively. The mean $\mathrm{EC}_{50}$ values of azoxystrobin, trifloxystrobin, and pyraclostrobin significantly increased in the nonbaseline isolates compared with baseline isolates, with a resistant factor of 6.0,3.5, and 3.0, respectively. Frequency of isolates with $\mathrm{EC}_{50}$ values $>10 \mu \mathrm{g} \mathrm{ml}^{-1}$ for azoxystrobin and trifloxystrobin increased from $25 \%$ in baseline isolates to $80 \%$ in nonbaseline isolates. Although sensitivity of nonbaseline isolates of $R$. solani to quinone outside inhibitors decreased, these fungicides at labeled rates were still effective at controlling the pathogen under greenhouse conditions.
\end{abstract}

Rhizoctonia solani Kühn (teleomorph Thanatephorus cucumeris (A. B. Frank) Donk) has been considered to be a major pathogen of sugar beet (Beta vulgaris L.) worldwide (Herr 1996; Whitney and Duffus 1986). It is a soilborne pathogen which survives as mycelium or sclerotia in the soil (Menzies 1970). R. solani has been considered a major pathogen since the early production of sugar beet crop. Since 2009, growers in North Dakota and Minnesota have listed Rhizoctonia spp. as their most important problem and reported that $11 \%$ of their fields were infested with $R$. solani (Carlson et al. 2013). R. solani has 14 anastomosis groups (AG), AG-1 to AG13 and AG-BI, which are further divided to subgroups (Carling et al. 2002). AG-1, AG-2-1, AG-2-2, AG-3, AG-4, and AG-5 have been recorded on sugar beet (Windels and Nabben 1989). The destructive AG on both seedling and older sugar beet plants is AG-2-2, which has two subgroups, AG-2-2 IIIB and AG-2-2 IV (Windels and Nabben 1989).

Growers typically use partially resistant cultivars and apply fungicides to manage $R$. solani in sugar beet (Kiewnick et al. 2001; Panella et al. 1994). Fungicides registered in the United States for control of $R$. solani on sugar beet include Quadris (azoxystrobin, active ingredient [a.i.], 22.9\%; Syngenta, Greensboro, NC), registered in 1999; Gem (trifloxystrobin, a.i., 42.6\%; Bayer, Research Triangle Park, NC), registered in 2002; Headline (pyraclostrobin, a.i., 23.6\%; BASF, Research Triangle Park, NC), registered in 2002; Proline (prothioconazole, a.i., 41\%; Bayer), registered in 2008; Vertisan (penthiopyrad, a.i., 20.6\%; DuPont Crop Protection, Wilmington, DE), registered in 2012 but not available commercially; Kabina 40SC (penthiopyrad, a.i., 40\%; Mitsui Chemicals Agro, Inc., Chuo-ku, Japan), which was labeled for use as a seed treatment and became available in 2013; and Priaxor (fluxapyroxad, a.i., 14.33\% + pyraclostrobin a.i., 28.58\%; BASF), which was labeled and became available in 2012 (Friskop et al. 2014).

Azoxystrobin, trifloxystrobin, and pyraclostrobin are quinone outside inhibitors (QoI), which block electron transfer between cytochrome $\mathrm{b}$ and cytochrome $\mathrm{c} 1$ by binding to cytochrome $\mathrm{b}$ and lead to halting the ATP production (Balba 2007). Penthiopyrad is a succinate dehydrogenase inhibitor (SDHI), which stops ATP production

Corresponding author: M. F. R. Khan; E-mail: Mohamed.khan@ndsu.edu

Accepted for publication 29 July 2016.

http://dx.doi.org/10.1094/PDIS-04-16-0525-RE

(C) 2016 The American Phytopathological Society by binding to succinate dehydrogenase enzyme located in mitochondrial membrane (Hägerhäll 1997). Prothioconazole is a sterol biosynthesis demethylation inhibitor (DMI), which disturbs plasma membrane structure and results in abnormal fungal growth and death (Georgopapadakou 1998). These groups of fungicides were classified by the Fungicide Resistance Action Committee as medium to high risk with regard to resistance evolution (Anonymous 2016).

Growers in the United States have been using azoxystrobin for control of $R$. solani in sugar beet since it was labeled in 1999. In 2013, growers in Minnesota and North Dakota, responsible for producing $57 \%$ of the U.S. sugar beet crop (Anonymous 2014), listed azoxystrobin, followed by pyraclostrobin, and prothioconazole, as the fungicides most commonly used to control $R$. solani (Carlson et al. 2013). Although fungicides have been used annually to manage $R$. solani, we are not aware of any peer review article which has evaluated sensitivity of $R$. solani AG 2-2 isolates from sugar beet to fungicides.

$R$. solani isolates from several different plants and regions were evaluated for their sensitivity to fungicides. For example, $R$. solani isolates from potato (Solanum tuberosum L.) (Campion et al. 2003), rice (Oryza sativa L) (Chen et al. 2012, 2014; Olaya et al. 2012; Sundravadana et al. 2007; Zhang et al. 2009), grasses (Blazier and Conway 2004; Martin et al. 1984), tobacco (Nicotiana tabacum L.) (Csinos and Stephenson 1999; LaMondia 2012), soybean (Glycine $\max$ (L.) Merr.) (Ajayi and Bradley 2014), and table beet (Olaya et al. 1994) were evaluated for their sensitivity to different group of fungicides. Some studies evaluated fungicide sensitivity of $R$. solani isolates from soil (Carling et al. 1990; Goll et al. 2014; Jin et al. 2009; Kataria et al. 1991). Some of these previous studies showed that $R$. solani has the ability to develop resistance to QoI fungicides, as was demonstrated by $R$. solani AG-1-1A from rice (Olaya et al. 2012) and AG-2-2 IIIB from turf grass (Blazier and Conway 2004).

It would be useful to determine baseline sensitivity of $R$. solani isolates from sugar beet to fungicides so that any changes in the pathogen's sensitivity could be monitored over time to determine how best to manage the fungus while preserving the utility of fungicides. This research was conducted to (i) develop baseline sensitivity data of $R$. solani AG-2-2 from sugar beet for QoI (i.e., azoxystrobin, trifloxystrobin, and pyraclostrobin), SDHI (i.e., penthiopyrad), and DMI (i.e., prothioconazole) fungicides and determine whether a shift in sensitivity to any or all of the tested fungicides has occurred since 1999; (ii) determine whether there was cross resistance between QoI fungicides; and (iii) evaluate the efficacy of the tested fungicides at controlling $R$. solani isolates in the greenhouse. 


\section{Materials and Methods}

Source of $\boldsymbol{R}$. solani isolates. $R$. solani AG-2-2 isolates were obtained from the University of Minnesota, Northwest Research and Outreach Center, Crookston (Dr. Carol Windels and Jason Brantner). These isolates were collected from sugar beet samples submitted by growers from Minnesota and North Dakota. In all, 105 R. solani AG-2-2 isolates were used in this study; of these, 27 isolates were used to establish a baseline for sensitivity because they were collected prior to 1999, before the labeled use of any foliar fungicide for control of $R$. solani in sugar beet. The remaining 78 isolates, collected between 2005 and 2012 (Table 1), after fungicides were labeled and widely used for control of $R$. solani, were used to determine whether a shift in sensitivity has occurred.

In vitro sensitivity of $R$. solani to azoxystrobin, trifloxystrobin, pyraclostrobin, penthiopyrad, and prothioconazole. A mycelial radial growth assay was used to evaluate $R$. solani sensitivity to the above-listed fungicides as described by Kataria et al. (1991), with slight modifications. A cork borer (number 3 ) was used to cut 5-mmdiameter mycelial plugs from the actively growing margin of 4-day-old cultures of $R$. solani. The plugs were inverted onto the fungicideamended (described later) and nonamended media and incubated at $22 \pm 2{ }^{\circ} \mathrm{C}$ in the dark for $72 \mathrm{~h}$. After incubation, the colony diameters were measured in two perpendicular directions. The percentage of mycelium growth reduction for each isolate and concentration was calculated as $[100-$ (diameter in amended media/diameter in nonamended media $\times 100$ )] and analyzed by regression analysis against the $\log$ fungicide concentration. The concentration that caused $50 \%$ mycelial growth inhibition $\left(\mathrm{EC}_{50}\right)$ was determined by interpolation of the 50\% intercept (Russell 2004) using SAS (version 9.3; SAS Institute, Inc.; Cary, NC). A completely randomized design was used, with two replications per fungicide concentration. The experiment was repeated once.

Technical grades of azoxystrobin ( $96 \%$ a.i.; Syngenta), trifloxystrobin ( $98.8 \%$ a.i.; Bayer), pyraclostrobin ( $98 \%$ a.i.; BASF), penthiopyrad

Table 1. Year of collection, state of origin, and number of Rhizoctonia solani AG-2-2 isolates $(N)$ and their subgroups from sugar beet used for mycelial radial growth assay and in greenhouse studies

\begin{tabular}{|c|c|c|c|c|}
\hline \multirow[b]{2}{*}{ Isolates, year } & \multirow[b]{2}{*}{ State } & \multirow[b]{2}{*}{$N$} & \multicolumn{2}{|c|}{$\begin{array}{c}\text { AG-2-2 } \\
\text { subgroups }(N)^{\mathrm{a}}\end{array}$} \\
\hline & & & IIIB & IV \\
\hline \multicolumn{5}{|l|}{ Baseline $^{b}$} \\
\hline 1986 & Minnesota & 5 & 1 & 4 \\
\hline \multirow[t]{2}{*}{1987} & Minnesota & 2 & 0 & 2 \\
\hline & North Dakota & 4 & 1 & 3 \\
\hline 1988 & Minnesota & 3 & 0 & 3 \\
\hline \multirow[t]{2}{*}{ 1987-1988 } & Minnesota & 3 & 0 & 3 \\
\hline & North Dakota & 4 & 0 & 4 \\
\hline 1989 & Minnesota & 1 & 0 & 1 \\
\hline 1993 & Minnesota & 5 & 2 & 3 \\
\hline Subtotal & $\ldots$ & 27 & 4 & 23 \\
\hline \multicolumn{5}{|l|}{ Nonbaseline $^{\mathrm{c}}$} \\
\hline \multirow[t]{2}{*}{2005} & Minnesota & 1 & 0 & 1 \\
\hline & North Dakota & 3 & 0 & 3 \\
\hline \multirow[t]{2}{*}{2006} & Minnesota & 14 & 5 & 9 \\
\hline & North Dakota & 6 & 2 & 4 \\
\hline 2007 & Minnesota & 12 & 9 & 3 \\
\hline \multirow[t]{2}{*}{2008} & Minnesota & 9 & 6 & 3 \\
\hline & North Dakota & 2 & 1 & 1 \\
\hline \multirow[t]{2}{*}{2012} & Minnesota & 30 & 15 & 15 \\
\hline & North Dakota & 1 & 0 & 1 \\
\hline Subtotal & $\ldots$ & 78 & 38 & 40 \\
\hline Total & $\ldots$ & 105 & 42 & 63 \\
\hline
\end{tabular}

${ }^{a} R$. solani AG-2-2 subgroups were determined following Sneh et al. (1991).

${ }^{\mathrm{b}} R$. solani isolates collected before 1999 , prior to the use of any foliar fungicide labeled for control of $R$. solani in sugar beet.

${ }^{\mathrm{c}} R$. solani isolates were collected from sugar beet fields during the period when quinone outside inhibitor and demethylation inhibitor fungicides were labeled and used in sugar beet.
(95\% a.i.; DuPont), and prothioconazole (99.4\% a.i.; Bayer) were used to prepare stock solutions of $100,000 \mu \mathrm{g} \mathrm{ml}^{-1}$ in acetone (EM Science, Gibbstown, NJ). The 10-fold serial dilutions were prepared to have fungicide concentrations of $0,10,100,1,000$, and 10,000 $\mu \mathrm{g} \mathrm{ml}^{-1}$. Salicylhydroxamic acid (SHAM; Sigma-Aldrich, St. Louis) was dissolved in methanol (Sigma-Aldrich) to obtain a stock solution of $10,000 \mu \mathrm{g} \mathrm{ml}^{-1}$. One liter of half-strength potato dextrose agar (PDA; HIMEDIA) medium was amended with $1 \mathrm{ml}$ of one of the fungicide concentrations and $1 \mathrm{ml}$ of SHAM, which was used to prevent an alternative oxidation respiration pathway (Wood and Hollomon 2003). Isolates that showed an $\mathrm{EC}_{50}$ value $\geq 100$ $\mu \mathrm{g} \mathrm{ml}^{-1}$, as was the case for azoxystrobin and trifloxystrobin, were tested again using fungicide concentrations of $0,1,10,100,500$, and $1,000 \mu \mathrm{g} \mathrm{ml}^{-1}$. Due to low solubility of the technical grades in water, formulated products of azoxystrobin (Quadris, $22.9 \%$ a.i.) and trifloxystrobin (Gem, $42.6 \%$ a.i.) were used to prepare fungicide concentrations as was reported by Kataria et al. (1991).

Efficacy of azoxystrobin, trifloxystrobin, pyraclostrobin, penthiopyrad, and prothioconazole in controlling $R$. solani AG-2-2. Efficacy of the above-listed fungicides for controlling $R$. solani AG-2-2 was evaluated in the Agricultural Experiment Station greenhouse at North Dakota State University in Fargo. Eight $R$. solani isolates were chosen based on the AG-2-2 subgroups and their $\mathrm{EC}_{50}$ values for azoxystrobin and trifloxystrobin. Four isolates of AG-2-2 IIIB (two isolates [22-1 and 571] with high $\mathrm{EC}_{50}$ values $[\geq 100 \mu \mathrm{g}$ $\mathrm{ml}^{-1}$ ] and two isolates [850 and 946] with low $\mathrm{EC}_{50}$ values $[<10 \mu \mathrm{g}$ $\left.\mathrm{ml}^{-1}\right]$ ) and four isolates of AG-2-2 IV (isolates 393 and 40-2 with high $\mathrm{EC}_{50}$ values and isolates 60 and 31-1 with low $\mathrm{EC}_{50}$ values) were chosen. Because of space limitation and the time required to prepare and inoculate the high number of treatments $(n=960)$, the isolates were divided and evaluated for all fungicides in two studies, and each study was repeated once.

Sunshine Mix LC1 (73 to 83\% Canadian sphagnum peat moss, perlite, and dolomite lime; Sun Gro Horticulture Distribution, Inc., Agawam, MA) was used to fill plastic trays ( 25 by 14 by $13 \mathrm{~cm}$; T. O. Plastic, Inc., Clearwater, MN) into which 10 sugar beet seeds of 'Crystal 539RR', susceptible to $R$. solani (Niehaus 2011), were planted in a $2-\mathrm{cm}$-deep furrow made in the middle of each tray. Serial fungicide dilutions $\left(0,0.1,1,10,100,1,000\right.$, and $\left.10,000 \mu \mathrm{g} \mathrm{ml}^{-1}\right)$ as well as one of the widely recommended field application rates (Khan 2000) of azoxystrobin at $3,292 \mu \mathrm{g} \mathrm{ml}^{-1}\left(672 \mathrm{ml} \mathrm{ha}^{-1}\right)$, trifloxystrobin at $2,330 \mu \mathrm{g} \mathrm{ml}^{-1}\left(256 \mathrm{ml} \mathrm{ha}^{-1}\right)$, pyraclostrobin at 3,392 $\mu \mathrm{g} \mathrm{ml}$ $\left(672 \mathrm{ml} \mathrm{ha}^{-1}\right)$, penthiopyrad at $9,656 \mu \mathrm{g} \mathrm{ml}^{-1}\left(2,192 \mathrm{ml} \mathrm{ha}^{-1}\right)$, and prothioconazole at $3,652 \mu \mathrm{g} \mathrm{ml}^{-1}\left(417 \mathrm{ml} \mathrm{ha}^{-1}\right)$ were prepared using water. Fungicides were applied as an in-furrow application using a Generation III Research Sprayer (DeVries Manufacturing, Hollandale, $\mathrm{MN}$ ) through a 4001E flat-fan nozzle calibrated to deliver the solutions at $138 \mathrm{kPa}$ and $6.3 \mathrm{~km} \mathrm{~h}^{-1}$. The order of treatments was started with the control (distilled water) and then with the fungicides from the lowest to highest concentrations. Distilled water was used to rinse the sprayer three times between fungicides. After applying the fungicides, one $R$. solani-inoculated barley grain (Gaskill 1968) was placed $1 \mathrm{~cm}$ to the side of each sugar beet seed. After inoculation, sugar beet seed and inocula were covered with LC1 mix. Trays were placed under greenhouse conditions at $20 \pm 2{ }^{\circ} \mathrm{C}$ and a 12 -h photoperiod (Argus Control Systems, Ltd., Surrey, British Columbia, Canada) and irrigated daily. Three weeks after treatments, plants were removed from trays and roots were washed carefully under running tap water and evaluated using a 0 -to- 7 scale, where $0=$ no disease, $1=$ crown area slightly scurfy, $2=<5 \%$ symptoms, $3=6$ to $25 \%$ symptoms, $4=26$ to $50 \%$ symptoms, $5=51$ to $75 \%$ symptoms, $6=>75 \%$ symptoms, and $7=$ root completely deteriorated (Scholten et al. 2001). To confirm that the symptoms were caused by $R$. solani, the fungus was reisolated from symptomatic plants by cutting three small pieces ( $2 \mathrm{~mm}$ each) of the infected roots that were immersed in $0.5 \% \mathrm{NaOCl}$ for $10 \mathrm{~s}$, rinsed twice in sterilized distilled water, and plated on $1.5 \%$ water agar media. Morphological characteristics were used to identify the pathogen (Parmeter 1970). A randomized complete block design with three replicates was used with isolates, fungicides, and concentrations as the factors. 
Data Analysis. Levene's homogeneity of variance test was used to determine whether the runs for each study could be combined for analysis. Student's $t$ test $(P=0.05)$ was used to test differences between mean $\mathrm{EC}_{50}$ of baseline and nonbaseline isolates. Correlation between $\mathrm{EC}_{50}$ values for $\mathrm{QoI}$ fungicides for $R$. solani isolates were determined using Pearson correlation analyses $(\alpha=0.05)$. The nonparametric Kruskal-Wallis test was used to analyze the greenhouse data, as described by Shah and Madden (2004). The disease severity median value was calculated for each tray, and the respective mean rank for all isolates, fungicides, and concentrations was calculated using PROC RANK in SAS. For each treatment, the ranked disease severities were used to estimate relative effects, standard errors, and the $95 \%$ confidence intervals using the SAS macro LD-CI (http://www.ams.med.uni-goettingen.de/sasmakr-de.shtml) to compare among different treatments (Shah and Madden 2004).

\section{Results}

In vitro sensitivity of $R$. solani to azoxystrobin, trifloxystrobin, pyraclostrobin, penthiopyrad, and prothioconazole. The two trials for each experiment were combined based on Levene's test for homogeneity of variance. Baseline isolates (isolates collected before 1999) showed $\mathrm{EC}_{50}$ values $\leq 3 \mu \mathrm{g} \mathrm{ml}^{-1}$ for pyraclostrobin, penthiopyrad, and prothioconazole and a wide range of $\mathrm{EC}_{50}$ values for azoxystrobin and trifloxystrobin (Table 2). The mean $\mathrm{EC}_{50}$ values were 49.7, 97.1, 0.32, 0.2, and $0.9 \mu \mathrm{g} \mathrm{ml}^{-1}$ and the ranges of $\mathrm{EC}_{50}$ values were 0.43 to $597.43,0.14$ to $823.54,0.04$ to $2.70,0.04$ to 2.27 , and 0.11 to $2.40 \mu \mathrm{g} \mathrm{ml}^{-1}$ for azoxystrobin, trifloxystrobin, pyraclostrobin, penthiopyrad, and prothioconazole, respectively (Table 2).

Nonbaseline isolates collected in 2005 through 2012 showed also a wide range of $\mathrm{EC}_{50}$ values for azoxystrobin and trifloxystrobin, with means of 269.1 and $341.7 \mu \mathrm{g} \mathrm{ml}^{-1}$, respectively (Table 2). Mean $\mathrm{EC}_{50}$ values were $0.9 \mu \mathrm{g} \mathrm{ml}^{-1}$ for pyraclostrobin, $0.2 \mu \mathrm{g} \mathrm{m}{ }^{-1}$ for penthiopyrad, and $0.6 \mu \mathrm{g} \mathrm{ml}^{-1}$ for prothioconazole (Table 2). The ranges of $\mathrm{EC}_{50}$ values were 0.18 to $876.58,0.09$ to $888.41,0.02$ to
$6.43,0.02$ to 0.61 , and 0.03 to $0.56 \mu \mathrm{g} \mathrm{ml}^{-1}$ for azoxystrobin, trifloxystrobin, pyraclostrobin, penthiopyrad, and prothioconazole, respectively (Table 2). When the nonbaseline isolates were compared with the baseline isolates, there were significant $(P \leq 0.05)$ increases in the mean $\mathrm{EC}_{50}$ values for azoxystrobin, trifloxystrobin, and pyraclostrobin (Table 2), with a resistant factor (mean $\mathrm{EC}_{50}$ value of nonbaseline isolates/mean $\mathrm{EC}_{50}$ of baseline isolates) of $6.0,3.5$, and 3 , respectively (Table 2). The frequency of isolates with $\mathrm{EC}_{50}$ values $>10 \mu \mathrm{g} \mathrm{ml}^{-1}$ for azoxystrobin and trifloxystrobin increased from $25 \%$ in baseline isolates to $>80 \%$ in nonbaseline isolates (Table 3 ). There was no shift in mean $\mathrm{EC}_{50}$ values between baseline and nonbaseline $R$. solani isolates evaluated for sensitivity to penthiopyrad and prothioconazole (Table 2).

There was a significant positive correlation in baseline isolates between $\mathrm{EC}_{50}$ values of pyraclostrobin and $\mathrm{EC}_{50}$ values of trifloxystrobin $(r=0.8 ; P<0.0001)$. In nonbaseline isolates, a significant positive correlation was found between $\mathrm{EC}_{50}$ values of azoxystrobin and trifloxystrobin $(r=0.65 ; P<0.0001), \mathrm{EC}_{50}$ values of azoxystrobin and pyraclostrobin $(r=0.3 ; P=0.01)$, and $\mathrm{EC}_{50}$ values of trifloxystrobin and pyraclostrobin $(r=0.38 ; P<0.0006)$.

Efficacy of different concentrations of azoxystrobin, trifloxystrobin, pyraclostrobin, penthiopyrad, and prothioconazole at controlling $\boldsymbol{R}$. solani in the greenhouse. For all isolates, except isolate 31 (AG-2-2 IV; low $\mathrm{EC}_{50}$ value), the low fungicide concentrations ( $\leq 10 \mu \mathrm{g} \mathrm{ml}^{-1}$ ) were not effective at controlling $R$. solani and the ranked mean disease severities were significantly different from the noninoculated control (no symptoms). Isolate 31 was effectively controlled by azoxystrobin, pyraclostrobin, penthiopyrad, and prothioconazole at concentrations $\leq 10 \mu \mathrm{g} \mathrm{ml}^{-1}$ because they did not result in disease severities that were significantly different from the noninoculated controls (Figs. 1 and 2).

All fungicides applied at concentrations greater than $1,000 \mu \mathrm{g} \mathrm{ml}^{-1}$, which included the recommended field application rates for all tested fungicides, were able to control all $R$. solani isolates because disease

Table 2. Mean effective fungicide concentration that inhibited mycelial radial growth by $50 \%\left(\mathrm{EC}_{50}\right)$ values of azoxystrobin, trifloxystrobin, pyraclostrobin, penthiopyrad, and prothioconazole for Rhizoctonia solani AG 2-2 isolates collected before 1999 (baseline isolates) and from 2005 to and including 2012 (nonbaseline isolates) from sugar beet fields in Minnesota and North Dakota ${ }^{\mathrm{a}}$

\begin{tabular}{|c|c|c|c|c|c|c|}
\hline \multirow[b]{3}{*}{ MOA $^{c}$} & \multirow[b]{3}{*}{ Fungicide } & \multicolumn{4}{|c|}{$\mathrm{EC}_{50}\left(\mu \mathrm{g} \mathrm{ml}^{-1}\right)^{\mathrm{b}}$} & \multirow[b]{3}{*}{$\mathbf{R F}^{\mathbf{d}}$} \\
\hline & & \multicolumn{2}{|c|}{ Baseline isolates } & \multicolumn{2}{|c|}{ Nonbaseline isolates } & \\
\hline & & Mean & Range & Mean & Range & \\
\hline QoI & Azoxystrobin & $49.7(65.43)$ & $0.43-597.43$ & $296.1(127.75)^{*}$ & $0.18-876.58$ & 6.0 \\
\hline QoI & Trifloxystrobin & $97.1(58.43)$ & $0.14-823.54$ & $341.7(94.28)^{*}$ & $0.09-888.41$ & 3.5 \\
\hline QoI & Pyraclostrobin & $0.3(0.64)$ & $0.04-2.70$ & $0.9(1.13)^{*}$ & $0.02-6.43$ & 3.0 \\
\hline SDHI & Penthiopyrad & $0.2(0.21)$ & $0.04-2.27$ & $0.2(0.12)$ & $0.02-0.61$ & 1.0 \\
\hline DMI & Prothioconazole & $0.9(0.35)$ & $0.11-2.40$ & $0.6(0.25)$ & $0.03-0.56$ & 0.7 \\
\hline
\end{tabular}

${ }^{a}$ Mycelial radial growth assay was conducted using potato dextrose agar media. Cultures were kept in darkness at $22 \pm 2{ }^{\circ} \mathrm{C}$ for 3 days.

${ }^{b}$ Values in parenthesis denote standard deviation; * indicates $\mathrm{EC}_{50}$ values significantly different from baseline isolates at $P=0.05$ following Student's $t$ test.

${ }^{\mathrm{c}}$ Mode of action (MOA): QoI = quinone outside inhibitors, $\mathrm{SDHI}=$ succinate dehydrogenase inhibitor, and DMI = demethylation inhibitor.

${ }^{\mathrm{d}}$ Resistant factor (RF) was derived from mean $\mathrm{EC}_{50}$ value of nonbaseline isolates/mean $\mathrm{EC}_{50}$ value of baseline isolates.

Table 3. Frequency of effective fungicide concentration that inhibited mycelial radial growth by $50 \%\left(\mathrm{EC}_{50}\right)$ values of azoxystrobin, trifloxystrobin, pyraclostrobin, penthiopyrad, and prothioconazole for 27 baseline Rhizoctonia solani isolates collected before 1999 and 78 nonbaseline isolates collected from 2005 through 2012 from sugar beet fields in Minnesota and North Dakota using a mycelial radial growth assay ${ }^{\mathrm{a}}$

\begin{tabular}{|c|c|c|c|c|c|c|}
\hline \multirow[b]{2}{*}{ Active ingredient } & \multirow[b]{2}{*}{ Isolate group } & \multicolumn{5}{|c|}{ Isolate frequency $(\%)$ at $\mathrm{EC}_{50}$ range $\left(\mu \mathrm{g} \mathrm{ml}^{-1}\right)$} \\
\hline & & $0.01-0.1$ & $0.1-1$ & 1-10 & 10-100 & $100-1,000$ \\
\hline \multirow[t]{2}{*}{ Azoxystrobin } & Baseline & 0.00 & 7.14 & 67.86 & 17.86 & 7.14 \\
\hline & Nonbaseline & 0.00 & 7.69 & 11.54 & 32.05 & 48.72 \\
\hline \multirow[t]{2}{*}{ Trifloxystrobin } & Baseline & 0.00 & 32.14 & 42.86 & 3.57 & 21.43 \\
\hline & Nonbaseline & 1.28 & 2.56 & 12.82 & 6.41 & 76.92 \\
\hline \multirow[t]{2}{*}{ Pyraclostrobin } & Baseline & 25.00 & 67.86 & 7.14 & 0.00 & 0.00 \\
\hline & Nonbaseline & 6.41 & 73.08 & 20.51 & 0.00 & 0.00 \\
\hline \multirow[t]{2}{*}{ Penthiopyrad } & Baseline & 64.29 & 32.14 & 3.57 & 0.00 & 0.00 \\
\hline & Nonbaseline & 19.23 & 80.77 & 0.00 & 0.00 & 0.00 \\
\hline \multirow[t]{2}{*}{ Prothioconazole } & Baseline & 0.00 & 57.14 & 42.86 & 0.00 & 0.00 \\
\hline & Nonbaseline & 3.85 & 82.05 & 14.10 & 0.00 & 0.00 \\
\hline
\end{tabular}

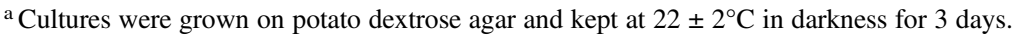


severities of plants treated with these fungicide concentrations were not significantly greater from those of noninoculated controls (Figs. 1 and 2).

\section{Discussion}

In this study, 105 isolates of $R$. solani AG-2-2 were tested for their sensitivity to azoxystrobin, trifloxystrobin, pyraclostrobin, penthiopyrad, and prothioconazole. Azoxystrobin, trifloxystrobin, and pyraclostrobin showed mean $\mathrm{EC}_{50}$ values of $49.7,97.1$, and $0.3 \mu \mathrm{g} \mathrm{ml}^{-1}$, respectively, for $R$. solani AG-2-2 baseline isolates. The mean $\mathrm{EC}_{50}$ values for azoxystrobin, trifloxystrobin, and pyraclostrobin increased to 296.1, 341.7, and $0.9 \mu \mathrm{g} \mathrm{ml}^{-1}$, respectively, in the AG-2-2 nonbaseline $R$. solani isolates. Although azoxystrobin, trifloxystrobin, and pyraclostrobin belong to the same fungicide group (QoI) (Balba 2007), the mean $\mathrm{EC}_{50}$ values of baseline and nonbaseline isolates suggested that pyraclostrobin had the greatest intrinsic activity. Pasche et al.

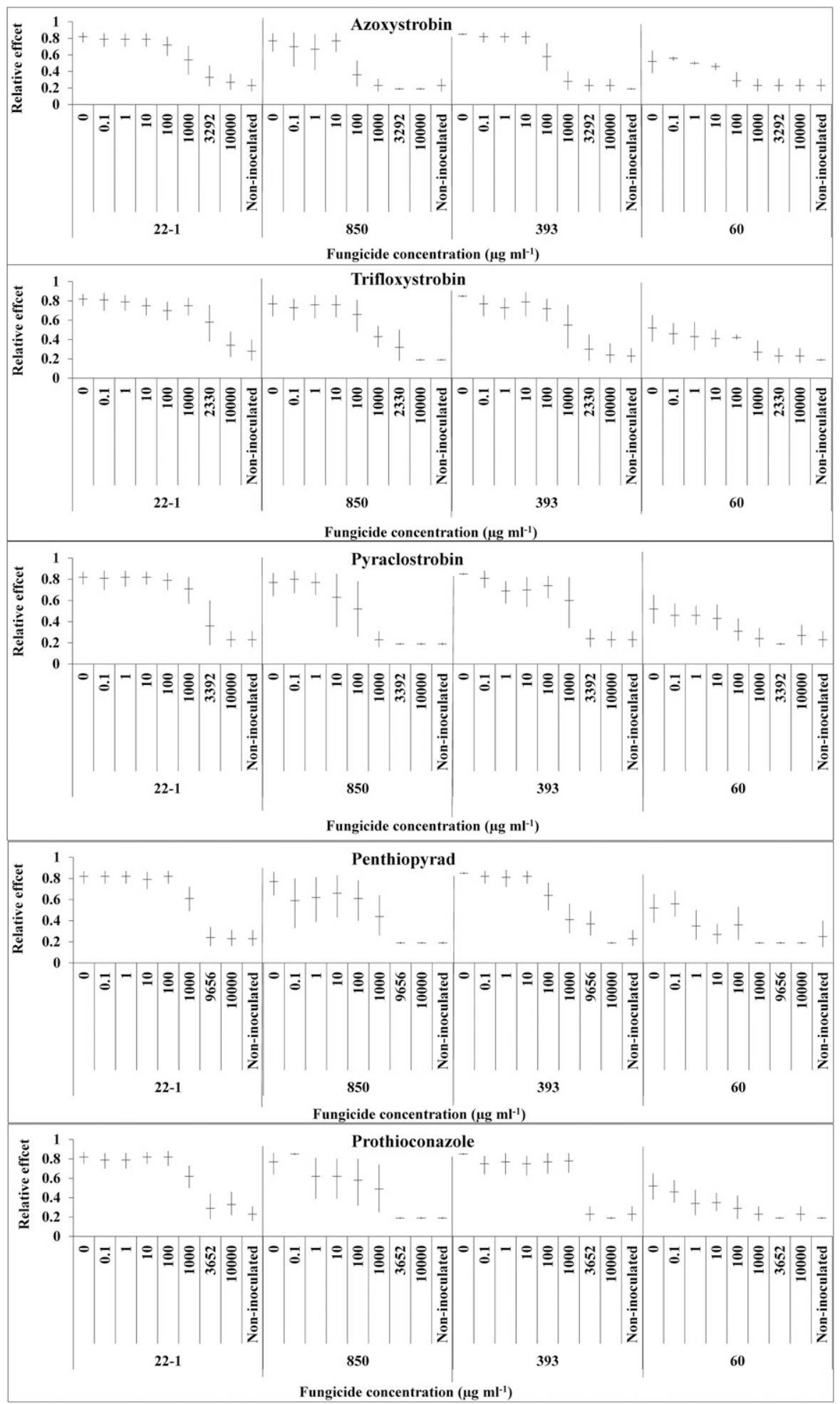

Fig. 1. Efficacy of five fungicides at controlling four Rhizoctonia solani isolates: two AG-2-2 IIIB isolates (22-1, with high concentration that caused $50 \%$ mycelial growth inhibition [EC ${ }_{50}$ ] value $\left[\geq 100 \mu \mathrm{g} \mathrm{ml}^{-1}\right]$ and isolate 850 , with low $\mathrm{EC}_{50}$ value $\left[<10 \mu \mathrm{g} \mathrm{ml}^{-1}\right]$ ) and two $\mathrm{AG} 2-2 \mathrm{IV}$ isolates (393, with high $\mathrm{EC}_{50}$ value and isolate 60 , with low $\mathrm{EC}_{50}$ value $\left[<10 \mu \mathrm{g} \mathrm{ml}{ }^{-1}\right]$ ) for azoxystrobin and trifloxystrobin using susceptible Crystal $539 R R$ sugar beet in the greenhouse. Plants were kept at $20 \pm 2^{\circ} \mathrm{C}$ and a 12 -h photoperiod for 3 weeks. Nonparametric analysis was used to analyze relative effects of each treatment on disease severity symptoms. There were three replicates for each treatment and the experiment was repeated once. 
(2004) and Wise et al. (2008) also reported similar results for Alternaria solani on potato (S. tuberosum L.) and Ascochyta rabiei on chick pea (Cicer arietinum L.), respectively.

In this study, azoxystrobin showed a high mean $\mathrm{EC}_{50}$ value $\left(\geq 100 \mu \mathrm{g} \mathrm{ml}^{-1}\right.$ ) for $R$. solani AG-2-2 (IIIB and IV, data not shown) isolates whereas Blazier and Conway (2004) reported a high mean $\mathrm{EC}_{50}$ value $\left(\geq 100 \mu \mathrm{g} \mathrm{ml}^{-1}\right)$ for AG-2-2 IIIB and low mean $\mathrm{EC}_{50}$ value for AG-2-2 IV, probably because of the low number $(n=4)$ of isolates evaluated. Jin et al. (2009) and Sundravadana et al. (2007) also reported low $\mathrm{EC}_{50}$ values for azoxystrobin but for just

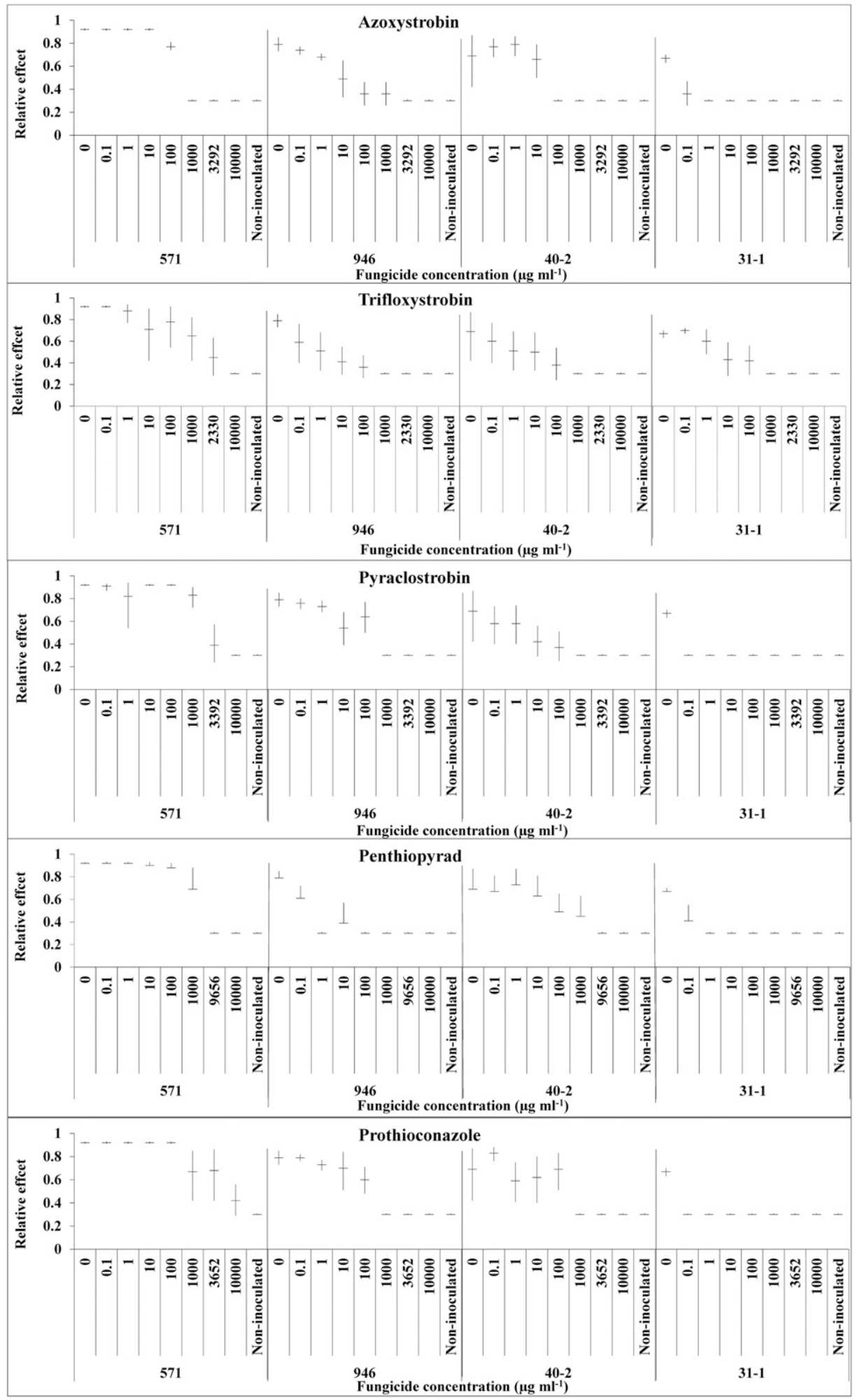

Fig. 2. Efficacy of five fungicides at controlling four Rhizoctonia solani isolates: two AG-2-2 IIIB isolates (571, with high concentration that caused $50 \%$ mycelial growth inhibition $\left[E C_{50}\right]$ value $\left[\geq 100 \mathrm{\mu g} \mathrm{ml}^{-1}\right]$ and isolate 946 , with low $\mathrm{EC}_{50}$ value $\left.\left[<10 \mu \mathrm{g} \mathrm{ml}^{-1}\right]\right)$ and two $A G$ 2-2 IV isolates $\left[40-2\right.$, with high $\mathrm{EC}_{50}$ value and isolate $31-1$, with low $E C_{50}$ value $\left[<10 \mu \mathrm{g} \mathrm{ml}^{-1}\right]$ ) for azoxystrobin and trifloxystrobin using susceptible Crystal 539RR sugar beet in the greenhouse. The inoculated and treated seeded trays were kept at $20 \pm 2^{\circ} \mathrm{C}$ and a 12-h photoperiod, and watered daily for 3 weeks. Nonparametric analysis was used to analyze relative effects of each treatment on disease severity symptoms evaluated using a scale of 0 (no disease) to 7 (root completely deteriorated). There were three replicates for each treatment and the experiment was repeated once. 
one tested $R$. solani isolate. These studies which reported low $\mathrm{EC}_{50}$ values for azoxystrobin did not have the isolates exposed to the fungicide as long as in our study.

The high $\mathrm{EC}_{50}$ values of azoxystrobin and trifloxystrobin in vitro could be a result of $R$. solani using an additional mechanism of alternative oxidation besides the alternative respiration pathway which is inhibited by SHAM, as was suggested by LaMondia, (2012) and Jin et al. (2009). In this study, $R$. solani isolates showed a low mean $\mathrm{EC}_{50}$ value for prothioconazole, similar to that reported by Ajayi and Bradley (2014). Other triazoles, including cyproconazole (Kataria et al. 1991), ipconazole (Ajayi and Bradley 2014), triadimefon (Martin et al. 1984), and hexaconazole (Carling et al. 1990), were also effective at reducing mycelial radial growth of $R$. solani. It was not surprising that there was no increase in prothioconazole mean $\mathrm{EC}_{50}$ value because this fungicide became available in 2006 and it was not widely used for control of $R$. solani in sugar beet (Carlson et al. 2013). In this study, penthiopyrad showed a low mean $\mathrm{EC}_{50}$ value for $R$. solani isolates collected prior to 1999 as well as isolates collected from 2005 to 2012 (Table 1), most likely because they were never exposed to the fungicide in the field since penthiopyrad was first used, in the form of a seed treatment, in 2014. Similarly, other baseline studies showed that SDHI, including thifluzamide, boscalid (Chen et al. 2012), and fluxapyroxad (Chen et al. 2014), had low $\mathrm{EC}_{50}$ values for $R$. solani.

In the in vitro study, $R$. solani AG-2-2 isolates showed a shift in sensitivity to the tested QoI fungicides. The resistant factor was 6.0, 3.5, and 3 for azoxystrobin, trifloxystrobin, and pyraclostrobin, respectively. Azoxystrobin, since becoming labeled in 1999, was recommended and was most commonly used for control of $R$. solani in the United States, including North Dakota and Minnesota (Khan 2000). Pyraclostrobin was labeled in 2002, became available in 2003, and, since then, was the most used fungicide (on 60 to $90 \%$ of planted acreage) for control of Cercospora beticola in Minnesota and North Dakota (Carlson et al. 2013). Around 2009, growers in this bistate area started using pyraclostrobin as an in-furrow application for the control of Rhizoctonia damping-off and root rot; however, it was not as widely used as azoxystrobin (Carlson et al. 2013). Trifloxystrobin was labeled for use on sugar beet in 2002 and used for control of $C$. beticola but in a relatively small area (1 to $10 \%$ of the sugar beet acreage) in southern Minnesota (Carlson et al. 2013). Growers have not listed trifloxystrobin (Gem) as a product they have used for control of $R$. solani in sugar beet (Carlson et al. 2013). The decrease in sensitivity of $R$. solani to azoxystrobin was probably due to its prolonged exposure to this fungicide with little or no rotation with other fungicide groups (Carlson et al. 2013); thus, high selection pressure on $R$. solani isolates could have occurred. It should be noted that one of the authors who works directly with growers and agriculturists in Minnesota and North Dakota did not observe or receive any report of a field failure of azoxystrobin for control of $R$. solani in sugar beet. It is also possible that resistance to QoI can occur over a short period of time (Pasche et al. 2004). Similarly, the increased usage of pyraclostrobin for control of $R$. solani could be driving the selection pressure for isolates with reduced sensitivity to pyraclostrobin. Because trifloxystrobin was not used as the other QoI for controlling $R$. solani (Carlson et al. 2013), the increase in its mean $\mathrm{EC}_{50}$ value could be due to its positive cross resistance with azoxystrobin, as was reported in this study and another study by Pasche et al. (2004).

In the in vivo study, AG-2-2 isolates with low and high $\mathrm{EC}_{50}$ values were controlled effectively by all tested fungicides at one of the recommended application rates (azoxystrobin at $672 \mathrm{ml} \mathrm{ha}^{-1}$, trifloxystrobin at $256 \mathrm{ml} \mathrm{ha}^{-1}$, pyraclostrobin at $672 \mathrm{ml} \mathrm{ha}^{-1}$, penthiopyrad at 2,192 $\mathrm{ml} \mathrm{ha}^{-1}$, and prothioconazole at $417 \mathrm{ml} \mathrm{ha}^{-1}$ ). Similarly, LaMondia (2012) reported that $R$. solani isolates with a high $\mathrm{EC}_{50}$ value for azoxystrobin could be easily controlled with the same fungicide under greenhouse conditions.

In conclusion, $R$. solani isolates shifted to reduced sensitivity (high $\mathrm{EC}_{50}$ values) for QoI fungicides. Although $R$. solani isolates had high $\mathrm{EC}_{50}$ values, they were still controlled by tested fungicides at labeled rates in vivo. It is possible that, with continued use of QoI fungicides, selection pressure for isolates with high $\mathrm{EC}_{50}$ values may result in populations of the pathogen which might not be controlled in the field, as occurred in rice fields in Louisiana (Olaya et al. 2012). In areas where $R$. solani isolates had high $\mathrm{EC}_{50}$ values to QoI fungicides, it will be necessary to develop, implement, and evaluate different management strategies that will provide effective disease control and manage fungicide resistance.

\section{Acknowledgments}

We thank C. Windels, A. Chanda, and J. Brantner from the University of Minnesota for providing Rhizoctonia solani isolates; and the Sugarbeet Research and Education Board of Minnesota and North Dakota and Western Sugar Cooperative for partially funding this research.

\section{Literature Cited}

Ajayi, O., and Bradley, C. A. 2014. Sensitivity of Rhizoctonia solani to SDHI and DMI fungicides. (Abstr.) Phytopathology 104:S3.4.

Anonymous. 2014. Sugar and Sweeteners Yearbook Tables. Online publication. USDA-ERS. http://www.ers.usda.gov/data-products/sugar-and-sweetenersyearbook-tables.aspx\#25440

Anonymous. 2016. FRAC Code List 2016: Fungicides Sorted by Mode of Action (Including FRAC Code Numbering). Fungicide Resistance Action Committee, Basel, Switzerland.

Balba, H. 2007. Review of strobilurin fungicide chemicals. J. Environ. Sci. Health Part B 42:441-451.

Blazier, S. R., and Conway, K. E. 2004. Characterization of Rhizoctonia solani isolates associated with patch diseases on turf grass. Proc. Okla. Acad. Sci. $84: 41-51$

Campion, C., Chatot, C., Perraton, B., and Andrivon, D. 2003. Anastomosis groups, pathogenicity and sensitivity to fungicides of Rhizoctonia solani isolates collected on potato crops in France. Eur. J. Plant Pathol. 109:983-992.

Carling, D. E., Baird, R. E., Gitaitis, R. D., Brainard, K. A., and Kuninaga, S. 2002 Characterization of AG-13, a newly reported anastomosis group of Rhizoctonia solani. Phytopathology 92:893-899.

Carling, D. E., Helm, D. J., and Leiner, R. H. 1990. In vitro sensitivity of Rhizoctonia solani and other multinucleate and binucleate Rhizoctonia to selected fungicides. Plant Dis. 74:860-863.

Carlson, A. L., Khan, M. F. R., and Boetel, M. A. 2013. Survey of fungicide use in sugar beet in Minnesota and eastern North Dakota in 2013. Online publication. Sugar Beet Research and Education Board. http://www.sbreb.org/research/ plant/plant13/plant13.htm

Chen, Y., Yao, J., Yang, X., Zhang, A. F., and Gao, T. C. 2014. Sensitivity of Rhizoctonia solani causing rice sheath blight to fluxapyroxad in China. Eur. J. Plant Pathol. 140:419-428.

Chen, Y., Zhang, A. F., Wang, W. X., Zhang, Y., and Gao, T. C. 2012. Baseline sensitivity and efficacy of thifluzamide in Rhizoctonia solani. Ann. Appl. Biol. $161: 247-254$

Csinos, A. S., and Stephenson, M. G. 1999. Evaluation of fungicides and tobacco cultivar resistance to Rhizoctonia solani incited target spot, damping-off and sore shin. Crop Prot. 18:373-377.

Friskop, A., Markell, S., and Khan, M. 2014. 2014 North Dakota field crop plant disease management guide. Bull. PP-622. North Dakota State University Extension Service, Fargo.

Gaskill, J. O. 1968. Breeding for Rhizoctonia resistance in sugar beet. Am. Soc Sugar Beet Technol. 15:107-119.

Georgopapadakou, N. H. 1998. Antifungals: Mechanism of action and resistance, established and novel drugs. Curr. Opin. Microbiol. 1:547-557.

Goll, M. B., Schade-Schutze, A., Swart, G., Oostendorp, M., Schott, J. J., Jaser, B., and Felsenstein, F. G. 2014. Survey on the prevalence of Rhizoctonia spp. in European soils and determination of the baseline sensitivity towards sedaxane. Plant Pathol. 63:148-154.

Hägerhäll, C. 1997. Succinate: Quinone oxidoreductases. Variations on a conserved theme. Biochim. Biophys. Acta 1320:107-141.

Herr, J. L. 1996. Sugar beet diseases incited by Rhizoctonia spp. Pages 341-349 in: Rhizoctonia Species: Taxonomy, Molecular Biology, Ecology, Pathology, and Disease Control. B. Sneh, S. Jabji-Hare, S. Neate, and G. Dijst, eds. Kluwer Academic Publisher, Dordrecht, The Netherlands.

Jin, L., Chen, Y., Chen, C., Wang, J., and Zhou, M. 2009. Activity of azoxystrobin and SHAM to four phytopathogens. Agric. Sci. China 8:835-842.

Kataria, H. R., Verma, P. R., and Gisis, U. 1991. Variability in the sensitivity of Rhizoctonia solani anastomosis groups to fungicides. J. Phytopathol. 133: 121-133.

Khan, M. F. R. 2000. 2000 Sugar Beet Production Guide. North Dakota State University Extension Service and University of Minnesota Extension Service, Fargo, ND.

Kiewnick, S., Jacobsen, B. J., Braun-Kiewnick, A., Eckhoff, J. L. A., and Bergman, J. W. 2001. Integrated control of Rhizoctonia crown and root rot of sugar beet with fungicides and antagonistic bacteria. Plant Dis. 85: 718-722.

LaMondia, J. A. 2012. Efficacy of azoxystrobin fungicide against sore shin of shade tobacco caused by Rhizoctonia solani. Tob. Sci. 49:1-3. 
Martin, S. B., Campell, C. L., and Lucas, L. T. 1984. Response of Rhizoctonia blights of tall fescue to selected fungicides in the greenhouse. Phytopathology 74:782-785.

Menzies, J. D. 1970. Introduction: The first century of Rhizoctonia solani. Pages 3-6 in: Rhizoctonia solani, Biology and Pathology. J. R. Parmeter, ed. University of California Press, Los Angeles.

Niehaus, W. S. 2011. Results of American Crystal's 2011 Official Coded Variety Trials. Online publication. Sugar Beet Research and Education Board. http:// www.sbreb.org/research/sugar/sugar11/sugar11.htm

Olaya, G., Abawi, G., and Barnard, J. 1994. Response of Rhizoctonia solani and binucleate Rhizoctonia to five fungicides and control of pocket rot of table beet with foliar sprays. Plant Dis. 78:1033-1037.

Olaya, G., Buitrago, C., Pearsaul, D., Sierotzki, H., and Tally, A. 2012. Detection of resistance to QoI fungicides in Rhizoctonia solani isolates from rice. (Abstr.) Phytopathology 102:S4.88

Panella, L. W., Ruppel, E. G., and Hecker, R. J. 1994. Registration of four multigerm sugar beet germplasms resistant to Rhizoctonia root rot: FC716, FC717, FC718, and FC719. Crop Sci. 34:291-292.

Parmeter, J. R. 1970. Rhizoctonia solani, Biology and Pathology. University of California Press, Berkeley and Los Angeles, CA.

Pasche, J. S., Wharam, C. M., and Gudmestad, N. C. 2004. Shift in sensitivity of Alternaria solani in response to QoI fungicides. Plant Dis. 88:181-187.

Russell, P. E. 2004. Sensitivity Baseline in Fungicide Resistance Research and Management. Crop Life International, Brussels.
Scholten, O. E., Panella, L. W., De Bock, T. S. M., and Lange, W. 2001. A greenhouse test for screening sugar beet (Beta vulgaris) for resistance to Rhizoctonia solani. Eur. J. Plant Pathol. 107:161-166.

Shah, D. A., and Madden, L. V. 2004. Non-parametric analysis of ordinal data in designed factorial experiments. Phytopathology 94:33-43.

Sneh, B., Burpee, L., and Ogoshi, A. 1991. Identification of Rhizoctonia Species. American Phytopathological Society, St. Paul, MN.

Sundravadana, S., Alice, D., Kuttalam, S., and Samiyappan, R. 2007. Azoxystrobin activity on Rhizoctonia solani and its efficacy against rice sheath blight. Tunisian J. Plant Prot. 2:79-84

Whitney, E. D., and Duffus, J. E. 1986. Compendium of Beet Diseases and Insects. American Phytopathological Society, St. Paul, MN.

Windels, C. E., and Nabben, D. J. 1989. Characterization and pathogenicity of anastomosis groups of Rhizoctonia solani isolated from Beta vulgaris. Phytopathology 79:83-88.

Wise, K. A., Bradley, C. A., Pasche, J. S., Gudmestad, N. C., Dugan, F. M., and Chen, W. 2008. Baseline sensitivity of Ascochyta rabiei to azoxystrobin, pyraclostrobin, and boscalid. Plant Dis. 92:295-300.

Wood, P. M., and Hollomon, D. W. 2003. A critical evaluation of the role of alternative oxidase in the performance of strobilurin and related fungicides acting at the QoI site of complex III. Pest Manage. Sci. 59:499-511.

Zhang, C. Q., Liu, Y. H., Ma, X. Y., Feng, Z., and Ma, Z. H. 2009. Characterization of sensitivity of Rhizoctonia solani, causing rice sheath blight, to Mepronil and Boscalid. Crop Prot. 28:381-386. 